habit, the latter being a deep water form; Physa gyrina is a species common in small ponds, while $P$. integra prefers river borders and $P$. say $i$ inhabits larger ponds and lakes; and similar variations in habit may be found in the species of various genera such as Bifidaria and Vertigo among terrestrial genera, and Amnicola and Pisidium among aquatic genera.

It is, therefore, not safe to jump at conclusions on the basis of mere relationship. A student of geology who would correctly measure the conditions which prevailed during the time of deposition of the various fossiliferous Pleistocene formations must not only accurately identify the fossil species, but he must learn to know the habits of the modern representatives of the same species. ${ }^{8}$

BOHUMIL SHIMEK

The State UNIVersity of Iowa

\section{RAMSAY HEATLEY TRAQUAIR}

IсHтHYOLOGISTs all over the world have read with profound regret of the death of Dr. Ramsay Heatley Traquair, the eminent authority on fossil fishes. Dr. Traquair had long been regarded as the dean of paleichthyology, and had been revered by those in his field, both for his personality and his scientific achievements, as few men ever were. It was a shock to them to realize that he was no more among them. His work in ichthyology was of a fundamental kind, like that of Huxley or of Johannes Müller in zoology, and much of it has long since become incorporated among the established principles of the science. Indeed, Dr. Traquair may be regarded as the founder of modern paleichthyology, and his name, we believe, will stand next to that of Louis Agassiz, as the most illustrious in the history of this science.

${ }^{8}$ A supplementary table of mollusks, containing twelve lists of fossils and six lists of shells obtained from modern drift along streams and lakes, has been published by the author, and will be sent on application to members who are specially interested.
Ramsay Heatley Traquair was born at Rhynd, Perthshire, July 30, 1840. He was the youngest son of a Scottish minister. As a boy, he was sent to a preparatory school in Edinburgh, where his quiet bearing and studiousness attracted the attention of his teachers. Almost from childhood he manifested a deep love of nature, and as a boy he frequented a small natural-history shop kept by an old woman in Edinburgh, where were displayed minerals, fossils and shellfish: these no doubt stimulated his imagination and helped to nurture a growing love of natural history. As he grew older, he would go on excursions into the hills around Edinburgh in quest of paleichthyological specimens. On one of these trips, the story runs, he found a nodule with a portion of a palæoniscid fish, and was greatly surprised to learn that no book then available gave an adequate account of it. It was his ardent love of natural history that led to his choice of medicine as a profession, for this was the only science, at that time, that afforded both a foundation for natural history studies and the means of a livelihood. He entered the University of Edinburgh as a student of medicine in his seventeenth year, and he seems to have been a good student. His holidays were spent in collecting and studying fossils. As the end of his studies approached, it became more and more plain to him that he ought not to practise his profession but seek an opening in science. $\mathrm{He}$ took his degree in 1862, receiving a gold medal for his thesis on the asymmetry of flatfishes. In this year, too, he published his first paper, "On the Occurrence of Trilobites in the Carboniferous Limestone of Fifeshire."

For several years after graduation he held minor posts in the school of medicine, first as prosector and later as demonstrator of anatomy. This period afforded him an opportunity of acquiring skill in making anatomical preparations, besides allowing him to be near his favorite fossil hunting grounds. During 1866-67, he held the professorship of natural history in the Agricultural College at Cirencester, where he taught botany and devoted his spare time to the study of local geology 
and fossil fishes. His well-known memoir on Pygopterus belongs to this period, having been published in 1867 .

During the next six years he held the chair of zoology in the newly established College of Science in Dublin. This post was more congenial than his previous ones, but it is plain, from the few papers published during these years, that he lacked materials for carrying on his studies in paleichthyology. His opportunity, however, came in full measure in 1873, when he was appointed keeper of natural history in the Museum of Science and Art (now the Royal Scottish Museum), at Edinburgh. Shortly before leaving Dublin he married Miss Phoebe Anna Moss, whose work as a painter was just beginning to attract attention ; $^{1}$ she is the daughter of the late Dr. William Moss, of Dublin.

Dr. Traquair held the post of keeper for thirty-three years, retiring in 1906 at the age of sixty-six. His most brilliant and most lasting work was done during this time. He had at his disposal a magnificent collection of paleozoic fishes, including the materials brought together by Hugh Miller and used by him in his preparation of "Old Red Sandstone" and other works. Moreover, within easy reach of Edinburgh were a number of localities where fossil fishes could be easily procured. But it should not be thought that Dr. Traquair devoted all his time, during these years, to his studies: he gave much attention to building up the zoological collections at the museum. The synoptic exhibit in this subject, which is displayed in a large square gallery, is one of the completest, and perhaps the best of its kind, in the world. It is the admiration of all zoologists who visit the museum.

${ }^{1}$ Mrs. Traquair is widely known for her mural decorations. Her principal work is the series of mural paintings in the Catholic Apostolic Church in Edinburgh, which took four years to complete and is mentioned as one of the sights of Edinburgh. She has also done exquisite work in book illumination, decorative bookbinding and in enameling. For an appreciation of Mrs. Traquair's work, see A. F. Morris, "A Versatile Art Worker," The International Studio, XXV., 1905, pp. 339-343.
A few years after Dr. Traquair's retirement his health began to fail and during the past year or two it was felt by his friends that the end could not be far off. He died in his seventy-third year, on November 22, 1912, in his beautiful home, at the foot of the Pentland hills, at Colinton, near Edinburgh.

Many honors came to Dr. Traquair in his lifetime. He was an honorary or corresponding member of many learned societies throughout the world, including the New York Academy of Sciences, to which he was elected in 1899. He became a member of the Royal Society of London in 1881; in 1893 his alma mater conferred on him an honorary LL.D. He received a number of medals in recognition of his services to science-the Neill medal of the Royal Society of Edinburgh in 1878, and the Makdougall-Brisbane in 1901; the Lyell medal of the Geological Society of London (1902), and a Royal medal of the Royal Society in 1907.

Dr. Traquair's studies were embodied in about 130 memoirs. $^{2}$ He was not a voluminous writer, as natural history writers go these days, but whatever came from his pen was so carefully, so conscientiously elaborated, that even his smaller papers were highly valued by those in his field. Fossil fishes are often very imperfectly preserved, and authors are occasionally carried away into seeing anatomical details where none really exist. But Dr. Traquair never let his imagination have sway where his specimens were imperfect. His accuracy was almost proverbial. Considering the vast amount of detail contained in his papers, it is remarkable how little of it has ever been debated. Indeed, Dr. Traquair has been considered by some even over careful, so that his results were sometimes held back for a long time before publication. Thus, Dr. A. S. Woodward has lately pointed out that Dr.

${ }^{2}$ A bibliography of Dr. Traquair's scientific writings appeared in the Geol. Mag., dec. v, Vol. VI., 1909, pp. 245-250. His last publication was the memoir, "Les Poissons Wealdiens de Bernissart," published in 1911 (Mém. Musée Roy. d'Hist. Nat. de Belgique, VI., pp. iv $+65,12$ pls.). 
Traquair had a specimen of Palcospondylus for years in his possession before publishing it to the world: he had apparently waited in the hope of being able to throw additional light on this elusive fossil.

The work of Dr. Traquair may be described as that of a morphologist working out anatomical structures as a key to relationships, rather than that of a systematist. Still he described, as one should, such new species as came his way-perhaps a hundred in all. His greatest service was in establishing clearly the limits and the relationships of certain of the larger groups, such as the lungfishes and the Actinopterygia, and in carrying their history back to the early Devonian. In his classic memoir on the Palæoniscidæ, he showed on evidence that is now accepted as incontrovertible-but which none the less was not at all evident before he took up these obscure fossils-that these fishes are related to the sturgeons, especially to such forms as Polyodon, and not, as previously believed, to the gar pikes. This conclusion was of far-reaching importance, leading to a modification of many other ideas of the inter-relationships of the groups of fishes. The flattened, compressed Platysomidæ, he proved, are a specialized branch of the Palæoniscidæ; and he showed conclusively that Cheirolepis was a primitive ganoid, not an Acanthodian, and thus traced back the history of the acanthopterygian fishes almost as far back as that of any other group. He was the first to prove that the Devonian Dipterus was a lungfish, and thus he extended the geological history of this group. He gave us a revised study of the Arthrodire, Coccosteus, on which one or two restorations by other writers were subsequently based; and it was he who first clearly defined the characters of Homosteus and of Phlyctconaspis. He was the first to bring together our scattered knowledge of Pterichthys and to give a restoration of this form; and he, also, worked out the anatomy of that primitive type, Drepanaspis. To Traquair also must be credited whatever knowledge we possess of those extraordinary forms Thelodus and Lanarkia, which gave us the first conception of the appearance and the structure of the earliest known vertebrates. Dr. Traquair also devoted considerable time to preparing monographs of the fishes of the Old Red Sandstone. These were published by the Paleontographical Society, and appeared in parts, as ready; these, unfortunately, are left unfinished.

These are only a few of the more far-reaching studies of Dr. Traquair which our limited space allows us to mention, but there was hardly a field of paleozoic ichthyology which he did not touch, and, as was well said by one of his biographers, he touched nothing that he did not adorn.

Personally, Dr. Traquair was a most charming man. In 1909 the writer had the privilege of seeing him almost daily at the museum or in his home. He was quiet and reserved in bearing, but he possessed a fund of humor that was all the more surprising because, on account of his quiet manner, it was not at first expected. One could not be with him many days without seeing that the man was far greater than his works. He had a deep appreciation for the beauties of nature. $\mathrm{He}$ had a great love for Scottish history and knew the legends concerning every name and place, whether it was Mons Meg or Holyrood Abbey. He was a most charming host, and the memory long lingers of having seen him the center of a circle at an afternoon tea, when he was the life of the whole company. He was very fond of flowers, and the artistically laid out rectangular garden, sloping down from the rear of the house at Colinton, near Edinburgh, gave him great delight, and he talked with genuine pleasure of its every plant. $\mathrm{He}$ was a student of modern languages, which were his hobby, and it was with amazement that one who knew only his work on fossil fishes heard him discourse, at length, on words and their history. He used to spend most of his vacations in Germany because of his great love for the language and for the ways of German savants; and he spoke the language fluently, and wrote it with a grace that is seldom achieved except in one's mother tongue.

Those who have known Dr. Traquair intimately are deeply grieved to have lost a wise and lovable friend.

I. HussakoF

american Museum of Natural History 